\title{
Integrating transportation and land use planning at the metropolitan level in North America: multilevel governance in Toronto and Chicago
}

\author{
Integrando o planejamento de transporte e de uso do solo em escala metropolitana \\ na América do Norte: governança multinível em Toronto e Chicago
}

Fanny R. Tremblay-Racicot ${ }^{[0]}$, Jean Mercier ${ }^{[b]}$

[a] Ph.D candidate in Urban Studies at Department of Geography and Urban Studies, Temple University, Philadelphia, PA United States, e-mail: ftracicot@hotmail.com

${ }^{[b]}$ Ph.D in public administration (SU), professor at Université Laval, Québec, QC - Canada, e-mail: jean.mercier@pol.ulaval.ca

\begin{abstract}
This article compares the policies and processes by which transportation and land use planning are integrated in metropolitan Toronto, Canada, and Chicago, in the United States. Using twenty-four semi-structured interviews with key informants, it describes the array of interventions undertaken by governmental and non-governmental actors in their respective domains to shed light on how the challenge of integrating transportation and land use planning is addressed on both sides of the border. Evidence concerning the political dynamics in Toronto and Chicago demonstrates that the capacity of metropolitan institutions to adopt and implement plans that integrate transportation with land use fundamentally depends on the leadership of the province or the state government. Although the federal government of each nation can bypass the sub-national level and intervene in local affairs by funding transportation projects that include land use components, its capacity to promote a coherent metropolitan vision is inherently limited. In the absence of leadership at the provincial or state level, the presence of a policy entrepreneur or a strong civic capacity at the regional level can be a key factor in the adoption and implementation of innovative reforms.
\end{abstract}

Keywords: Transportation planning. Land use planning. Multilevel governance. Case study. Metropolitan organizations.

\section{Resumo}

Este artigo compara as políticas públicas e os processos pelos quais o planejamento de transporte e uso do solo estão integrados na área metropolitana de Toronto (Canadá) e de Chicago (Estados Unidos). A partir de 24 entrevistas semiestruturadas com respondentes chave, descreve-se a sequência de intervenções efetuadas por atores governamentais e não governamentais em seus respectivos domínios, para esclarecer como os desafios de integrar o planejamento de transportes e do uso do solo são geridos em ambos os lados. Evidências da dinâmica política em Toronto e em Chicago demonstram que a capacidade das instituições metropolitanas de adotarem e implementarem planos que integrem transporte e uso do solo dependem essencialmente da liderança da cidade polo ou do governo estadual. Embora o governo federal de cada país possa passar sobre o 
nível subnacional e intervir em questões locais através do financiamento de projetos de transporte que incluamo uso do solo como componente, sua capacidade de promover uma visão metropolitana coerente é inerentemente limitada. Na ausência de liderança no nível da província ou do estado, a presença de um empreendedor da política pública ou uma forte capacidade cívica regional podem se consolidar como elementos chave na adoção e implementação de reformas inovadoras.

Palavras-chave: Planejamento de transporte. Planejamento de uso do solo. Governança multinível. Estudo de caso. Organizações metropolitanas.

\section{Context}

Metropolitan regions across North America are facing increasingly complex issues related to transportation and land use: congestion, infrastructure costs, air pollution, greenhouse gas emissions, resource impacts and personal costs resulting from sprawling development (MARGERUM et al., 2011). Institutional fragmentation and the diffuse nature of authority, which is spread across jurisdictions and levels of government in federal systems, contribute to the complex nature of these problems (BROWN, 2012). Academic and governmental responses to the problems facing metropolitan regions have produced mixed results. Various academic research and advocacy trends are addressing transportation and land use concerns under different labels, such as "smart growth", "new urbanism", "sustainable transportation", and "transit-oriented development", but these approaches based on urban forms or physical means alone fail to address the structural nature of the problems rooted in institutional and political dynamics, problems that ultimately impede the implementation and practical effect of physical plans (SWANSTROM, 2011; NEUMAN, 2005; WHEELER, 2002). In addition, although governments have implemented several structural and procedural reforms to better integrate or coordinate regional transportation and land use decisions, little is known of the effects of different governmental structures and mechanisms on planning outcomes (MARGERUM et al., 2011).

This article contributes to filling this gap in the literature by comparing the cases of two cities that have recently experienced institutional reforms of metropolitan governance to better integrate transportation and land use planning. In those two cities, Toronto (Canada) and Chicago (United States), the provincial and state governments followed two different paths towards regional planning: the government of Ontario adopted a legislative and centralized approach, whereas the government of Illinois opted for a decentralized model of governance. By comparing two "opposite" structural reforms, our aim is descriptive and exploratory. Using twelve semi-structured interviews with key respondents in each city, we characterize two different multilevel governance frameworks for decision-making to reveal how public and private actors have addressed this new, complex issue of integrating transportation and land use planning at the metropolitan level. Because the structure of authority is fragmented among multiple jurisdictions (especially in federal regimes), the study of institutional reforms, intergovernmental relations and the relationships among public authorities, market forces and civil society is key to understanding the contemporary metropolis and urban transitions to sustainability.

The article begins by situating the issue of integrating transportation and land use planning and the debate on institutional structures at the metropolitan level in the academic literature. The methodology employed is then explained, along with an overview of Toronto and Chicago metropolitan areas. The results are presented by city and by level of authority, e.g., federal, provincial or state, metropolitan and local. We conclude with a discussion on the impacts of the structure of authority on the planning process and power dynamics, as well as the limitations and theoretical implications of this study.

\section{Background}

This section addresses the paradigm shift in transportation planning and the importance of integrating transportation and land use, as well 
as the institutional question at the regional level, including the multilevel governance approach.

Integrating transportation and land use

The relationship between transportation and land use as well as the effect of policies on the travel and location choices of businesses and individuals are difficult to measure and subject to debate (CERVERO; DUNCAN, 2006; FORSYTH; OAKES; SCHMITZ, 2007; GIULIANO, 1995; HANDY; CAO; MOKHTARIAN, 2005; NEUMAN, 2005; TRANSPORTATION RESEARCH BOARD, 2009). However, the necessity of coordinating transportation and land use planning is becoming widely acknowledged. A new paradigm in transportation planning changes the definition of the problem and its solutions, bringing transportation demand-management strategies to the forefront (LITTMANN, 2013). Whereas the mobility paradigm adopted in the past evaluated the efficiency of transportation systems based upon the speed, cost, and convenience of motorized travel, which favors solutions oriented towards automobile travel and roadway expansion; the new paradigm, oriented towards access to services and activities, considers a broader range of modes, objectives, impacts and improvement possibilities (LITTMANN, 2013; JOHNSTON, 2004). The paradigm shift from a mobility standpoint to an accessibility objective demands new strategies, such as reducing sprawling development, improving air quality, increasing population density, allowing for a mix of land uses and functions, improving transit services, and directing population growth towards built up areas where transit service is already provided, all of which requires planners to conceive of transportation and land use as components of the same system (BLACK, 2010; JOHNSTON, 2004).

The recognition of the need to integrate transportation with land use has entered the policy arena in a number of jurisdictions. In the United States, the adoption of the Intermodal Surface Transportation Efficiency Act (ISTEA) in 1991, the Transportation Equity Act for the 21st Century (TEA-21) in 1998, and the Safe, Accountable, Efficient, Transportation Equity Act: A Legacy for Users (SAFETEA-LU) in 2005 have contributed to redefining the transportation paradigm at the federal level by broadening the scope of funding programs to include transit, alternative modes of transport, land use, and other regional goals that go beyond increasing mobility, such as social, economic and environmental responsibility (WEIR; RONGERUDE; ANSELL, 2009; HAMILTON; HOKKANEN; WOOD, 2008; WHEELER, 2002). However, little is known about how these pieces of legislation translated into the policies and practices of lower-levels of government and quasi-governmental organizations at the state and local levels. State and local governments have been resisting the devolution of powers to the metropolitan level, and metropolitan planning organizations continue to face limits on their funding and implementation capabilities, despite federal efforts to increase their influence (HAMILTON; HOKKANEN; WOOD, 2008; WEIR; RONGERUDE; ANSELL, 2009; LEWIS; SPRAGUE, 1997).

\section{The institutional question at the metropolitan level}

The origins of the contemporary debate on institutional fragmentation at the metropolitan level can be traced back to the 1950s, when the post-WWII economic boom and the construction of highways across North America led to rapid suburban growth. The academic debate of that era pitted proponents of metropolitan reform, or consolidationists, against the public choice theorists of regionalism, until the emergence of "new regionalisms" in the 1990s. This section addresses the arguments of each school of thought and introduces the multilevel governance approach to policy making.

The metropolitan reform school identified institutional fragmentation as the cause of numerous problems and suggested the creation of a single local government corresponding to the geographical boundaries of the metropolitan region by merging or consolidating contiguous municipalities. The negative consequences of jurisdictional fragmentation were exposed in 1400 Governments, in which Robert Wood explained how the multiplicity of municipalities and the system of quasi-governmental agencies in the New York metropolitan area were leading to governmental inefficiency in service delivery, fiscal inequity among municipalities of the same region, and a mismatch between public resources 
and social needs (WOOD, 1961). In the same vein, Arthur Maas (1959) identified the absence of a metropolitan government as the 'missing link' in the American territorial division of powers. Recognizing the resistance of state governments to a potential devolution of powers to the metropolitan level, Maas suggested the possibility of an incremental and functional approach to governmental reform, focusing on transportation, by nature a regional issue (MAAS, 1959). Inefficiency and inequity resulting from jurisdictional fragmentation were thus the leitmotiv of the metropolitan reform school, which regarded consolidation as an optimal solution.

Conversely, the public choice school of regionalism, which was particularly popular in the 1980s, justified jurisdictional fragmentation (or "differentiation") at the metropolitan level by attempting to demonstrate the advantages of a competitive local government system for economic development and regional prosperity. This school, based on the works of Charles Tiebout (1956), perceived the fragmented system of local government as a public market in which each municipality offers a different package of goods and services. In this context, the customers/ residents "vote with their feet" by moving into a municipality corresponding to their preferences in terms of services and taxation, thereby providing a solution to the free-rider problem at the regional level. Proponents of the public choice school are thus in favor of a competitive, fragmented system of government at the regional level, assuming that residents have access to all of the information they require to make a rational choice among the different combinations of tax and services and the capacity to move to the location corresponding to their preferences.

More recently, "new regionalisms", a collection of viewpoints emphasizing the need to integrate physical planning, urban design, and equity planning to solve the problems of sprawling development, inequity, congestion and environmental degradation, have proposed regional collaboration as a vector of change (WHEELER, 2002). Movements promoting "new urbanism," smart growth, livable communities and sustainable development suggest changing the urban form, as opposed to the structure of government, in metropolitan regions (CALTHORPE; FULTON, 2001). In other words, these approaches to urban planning call for the integration of transportation and land use but do not suggest a modus operandi for doing so at the political and institutional levels, other than improved collaboration between public authorities and stakeholders. Another approach to new regionalism demands greater intraregional equity and institutional reforms, such as the regional tax-sharing systems implemented in Minneapolis-St Paul in 1975 (RUSK, 1993; DOWNS, 1994; ORFIELD, 1997). Also under the umbrella of new regionalism are the second- and thirdgeneration growth management strategies, originally developed in the 1970s in Oregon and adopted in Florida, Maine, Maryland, New Jersey, Rhode Island, Vermont, and Washington State (PORTER, 1992; DEAL; KIM; CHAKRABORTY, 2009). The aim of growth management policies is to direct residential and employment growth to specific zones at the regional level. State governments enact such policies, typically obliging municipalities to act in conformity with growth policies through comprehensive planning documents. Empirical studies demonstrate that growth management strategies can contribute to increasing transit use by limiting the abandonment of central neighborhoods (DEAL; KIM; CHAKRABORTY, 2009 , p. 21). However, as growth management policies or regional governments are not considered politically realistic, the advocates of new regionalism tend to propose solutions based on the incremental development of social capital, ad hoc sectoral collaboration initiatives, and frameworks of incentives and mandates between different levels of government (WHEELER, 2002; BRENNER, 2002; ALEXANDER, 2011; NELLES, 2013). In other words, new regionalists favor policy instruments of governance, as opposed to regulation.

Many types of public interventions are implemented to address the issue of jurisdictional fragmentation at the metropolitan level, such as municipal consolidation and the creation of local governments corresponding to the geographic boundaries of the region. Another option consists of creating regional special purpose bodies of various forms: governmental or quasi-governmental, voluntary or statutory, with an appointed or an elected board, with a more general or specific mandate, with a shared administration or having its own, etc. (NORTON, 1994: 110-112). In general, European countries have opted for consolidation and the integration of structures and services, whereas 
the United States has opted for the creation of special purpose authorities and relied on voluntary collaboration (NORTON, 1994). Although their establishment is a response to complexity, the proliferation of special purpose bodies in the United States exacerbates institutional fragmentation to the extent that the entanglement of jurisdictional boundaries is described as "organized chaos" (KRAWCHENKO, 2011; NORTON, 1994).

In this increasingly complex context, a growing body of academic literature focuses on multilevel governance, or the vertical and horizontal relationships among levels of government, quasigovernmental authorities, market forces and civil society (ALEXANDER, 2011; BRENNER, 2002; HORAK; YOUNG, 2012; NELLES, 2013; WEIR; RONGERUDE; ANSELL, 2009; WHEELER, 2002). Some authors note the limits of collaborative/ deliberative processes in regional planning and argue for state-mandated regional planning reforms (ALEXANDER, 2011; WEIR, 2000). Another body of research evaluates the strengths of horizontal partnerships at the regional level and assesses how they can participate in political decisions with superior levels of government (WEIR; RONGERUDE; ANSELL, 2009; NELLES, 2013). The urban governance approach stresses the importance of new institutional structures linking the government, the business community and civil society. While more difficult to manage than conventional governmental agencies, these new institutions can play a crucial role in navigating complex urban political environments (PIERRE; PETERS, 2012). This study contributes to this new body of literature by exploring how transportation and land use planning are integrated at the regional level in two metropolitan areas that recently underwent policy and institutional reforms of opposite natures.

\section{Research method \& presentation of cases}

This research is based on a comparative case study of two metropolitan regions: Toronto, located in the southern part of the Province of Ontario (Canada), and Chicago, located in the northeastern part of the State of Illinois (United States). This pair of cases was selected because although both regions are major transportation hubs in their respective countries and share similar geographies and populations, they have taken opposite paths in redesigning their institutional frameworks for metropolitan governance to address the challenge of integrating transportation and land use development.

The nature of our inquiry, the aim of which is to identify and explain policy choices and decision-making processes, requires a qualitative approach. Our primary data come from twelve semi-structured interviews with key informants at various levels of government and stakeholders in each region (federal, province/state, city, metropolitan authorities, transit operators, and non-profits). The respondents were asked to identify policies for sustainable transportation, report whether these policies included land use components, and describe the decision-making process and intergovernmental relations leading to their adoption and implementation. The interviews were conducted and transcribed by three research assistants from Université Laval and the University of Toronto between 2011 and 2013. Secondary sources, such as policy documents and organizations' websites, were also used as the means of triangulation and sources of factual information. This article is exploratory and inductive - of the responses to the questionnaire, which addressed multiple aspects of sustainable transportation including the physical, social and political environment, as well as policy instruments, only those related to transportation and land use planning, the decision-making process, and intergovernmental relations were included in the analysis.

\section{Overview of metropolitan Toronto and Chicago}

The map in Figure 1 illustrates the Great Lakes basin region in North America. Both cities, circled in red, are located on a lakeshore: Toronto on Lake Ontario, and Chicago on Lake Michigan. Although the presence of a lake constricts regional growth to the shores and inland, a flat topography allows for sprawling development. The satellite views images in Figures 2 and 3 illustrate this extension of both urban perimeters that go well beyond the municipal boundaries of Toronto and Chicago. The data in Table 1 also demonstrate the extent of sprawl and institutional fragmentation in both regions. 


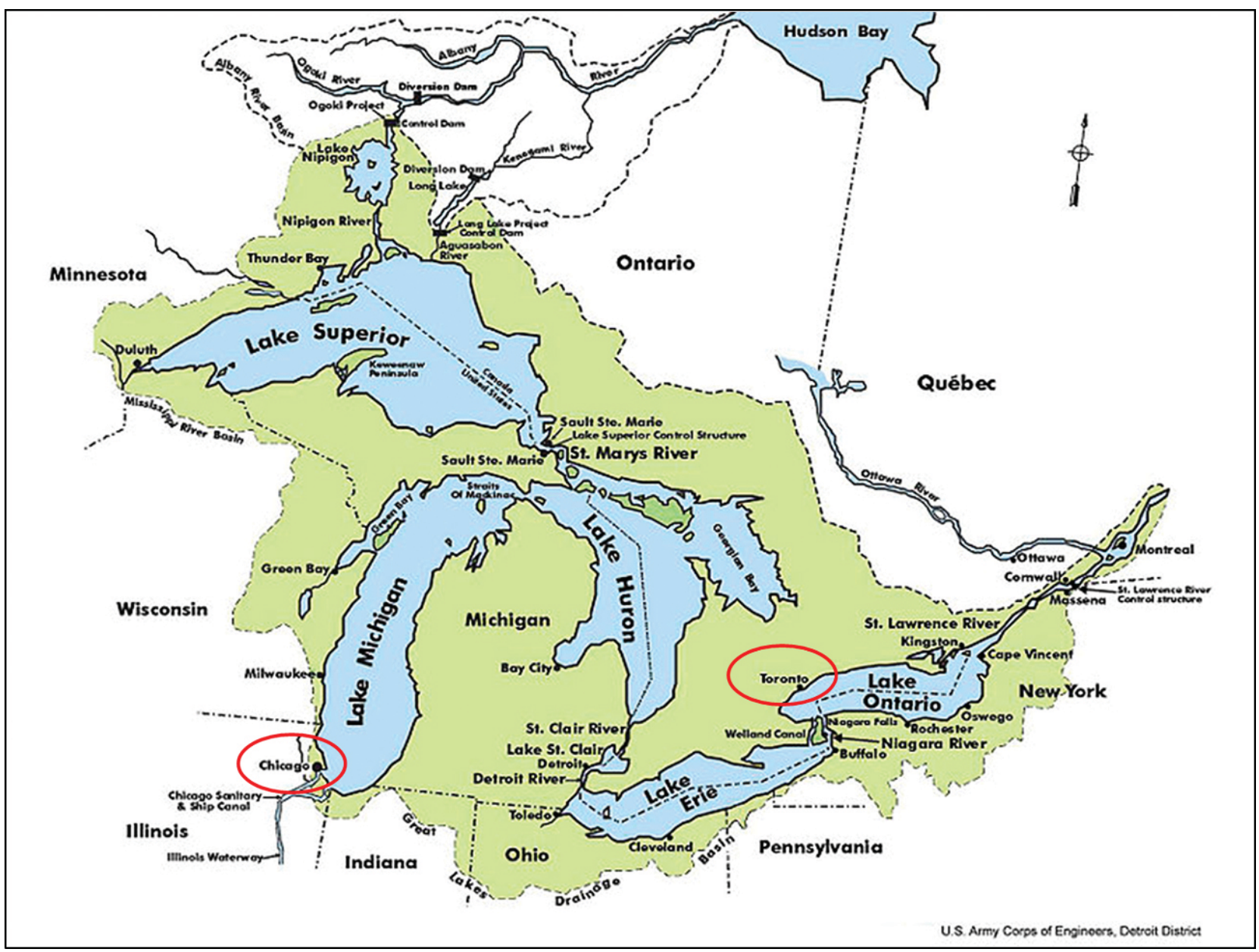

Figure 1 - Great Lakes Basin (Canada \& U.S.A)

Source: U.S. ARMY CORPS OF ENGINEERS, 2007.

The Toronto metropolitan region, the largest and most populous urban region in Canada, runs along the western end of Lake Ontario, taking the shape of a horseshoe (hence the name Golden Horseshoe) (see Figure 2). The Greater Toronto and Hamilton Area (GTHA) comprises two single-tier municipalities, Toronto and Hamilton, as well as four regional municipalities, i.e., Durham, Halton, Peel and York, and their associated 24 lower-tier municipalities. The Chicago metropolitan region, the third most populous in the United States, is located on the southwestern shore of Lake Michigan (see Figure 3). The region under the jurisdiction of the metropolitan planning organization (MPO), the Chicago Metropolitan Agency for Planning (CMAP), includes seven counties, i.e., Cook, DuPage, Kane, Kendall, Lake, McHenry and Will, totaling 284 municipalities. However, the boundaries of the Chicago Metropolitan Statistical Area include a portion of northwest Indiana that is not under CMAP jurisdiction. This southwestern region of Chicago, which includes Gary (Indiana) and 40 other cities and towns, is governed by a different MPO, the Northwestern Indiana Regional Planning Commission.

The data in Table 1 demonstrate that the two cities have similar populations, territory, and population density, although Chicago is somewhat larger, denser and more populous. The most important difference is the extent to which the cities are institutionally fragmented or, simply, the number of municipalities in the metropolitan regions. There are 26 municipalities and four regional municipalities in the GTHA, compared to 284 municipalities and seven counties in the region under the jurisdiction of CMAP. Moreover, the population of Toronto residing in the city proper represents $40 \%$ of the total population, whereas Chicagoans living within the 


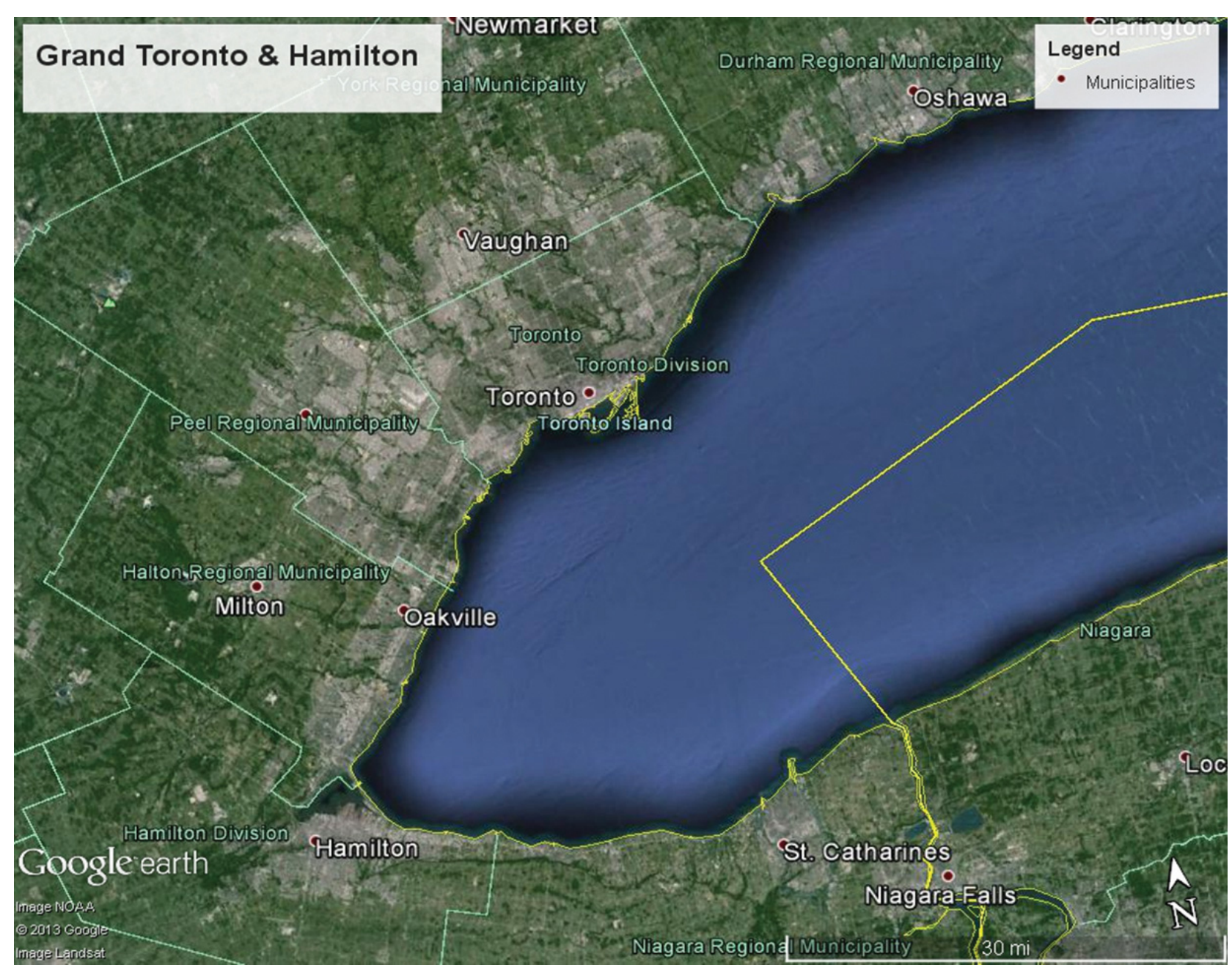

Figure 2 - Greater Toronto \& Hamilton Area (GTHA)

Source: Author, based on Google Earth Image (2013).

city boundaries represent $31 \%$ of the total regional population. As discussed later in this paper, the greater fragmentation in the Chicago metropolitan area complicates the regional planning process.

In addition to their similarities in terms of geography and population, each city recently acquired a new regional planning agency, reflecting the different attempts of provincial and state authorities to address planning challenges in the two regions. In Toronto, Metrolinx was established in 2006 by the government of Ontario to coordinate transportation planning in the GTHA. The creation of Metrolinx was the transportation component of a broader strategy launched by the provincial government to manage demographic and employment growth in the region. In Chicago, the transportation planning commission (Chicago Area Transportation Study - CATS) and the land use planning commission (Northeastern Illinois Planning Commission - NIPC) were merged by the government of Illinois in 2005 to establish the Chicago Metropolitan Agency for Planning (CMAP), responsible for integrating transportation and land use planning in the region. The nature of these institutional reforms is discussed in the following section.

\section{Policy \& praxis in Toronto \& Chicago}

This section addresses policies and practices for integrating transportation and land use development in Toronto and Chicago, as identified by the respondents. Reforms and interventions are categorized according the level of authority that 


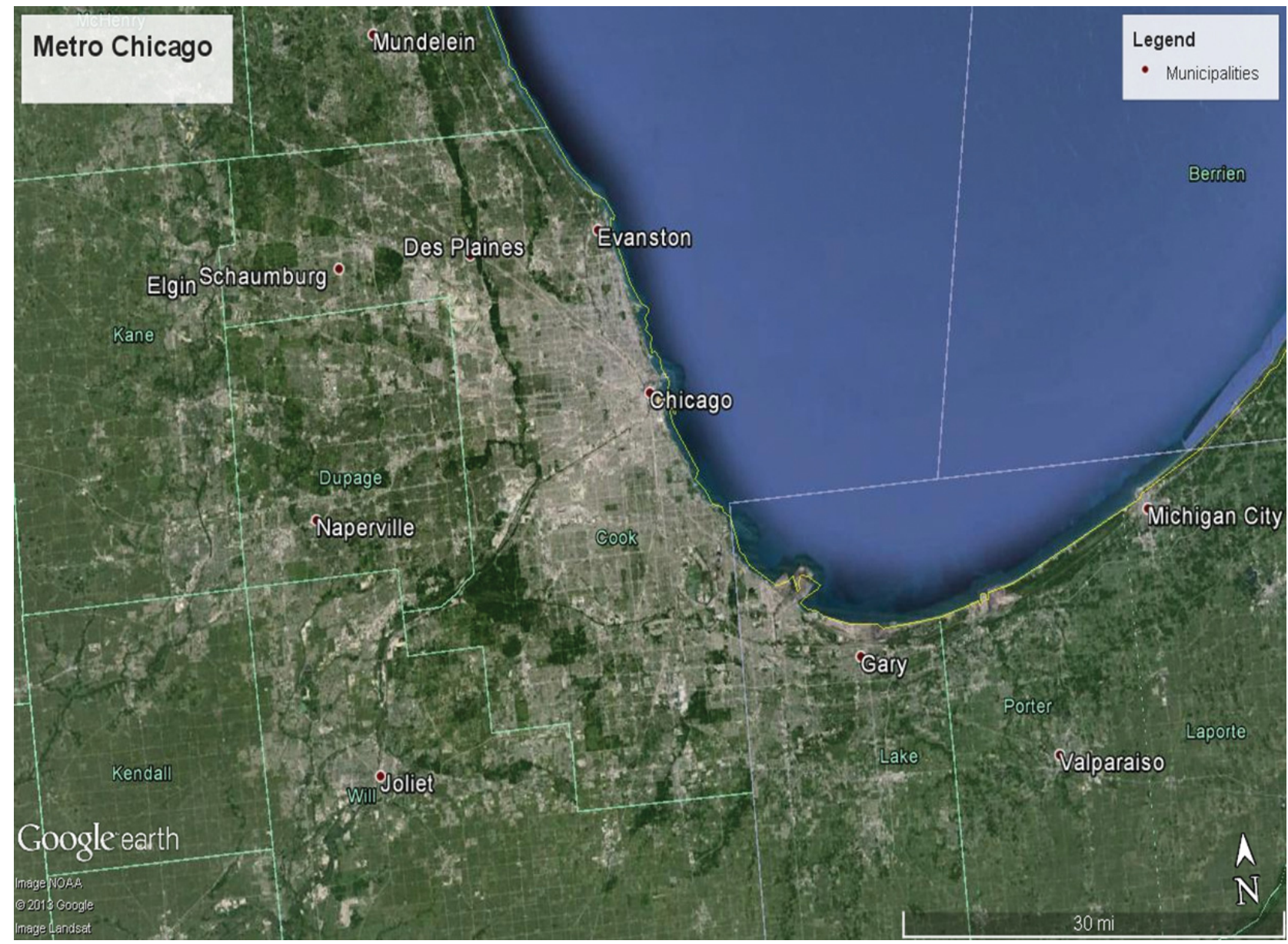

Figure 3 - Chicago Metropolitan Region

Source: Author, based on Google Earth Image (2013).

enacted or instigated them, i.e., the federal and provincial (Ontario) or state (Illinois), metropolitan, and municipal levels.

\section{Toronto}

Federal Government (the departments of Infrastructure Canada \& Transport Canada) Total federal contributions to transit projects across Canada reach $\$ 10$ billion annually. In Toronto, the federal government is a financial partner of GO Transit, the regional public transit service, and the Toronto Transit Commission, the subway, tramway, and bus operator. Federal grants for urban transportation infrastructure are motivated by economic competitiveness objectives, and they are not part of any policy or transportation plan. Our respondents identified no federal policy on urban transportation or program related to land use, as the conservative government of Prime Minister Steven Harper does not directly intervene in this arena, explicitly stating that land use and urban affairs in general are the purview of provincial governments and not the constitutional mandate of the national government. This position departs from the previous liberal administrations of Prime Ministers Jean Chretien and Paul Martin, who introduced the New Deal for Cities and Communities in 2005, which instituted the transfer of half of the federal gas tax to provinces and municipalities for sustainable infrastructure projects, including public transit. Under the liberal governments, every municipality was required to develop an integrated sustainability plan demonstrating how federal gas tax revenues would be invested in projects reducing greenhouse gas emissions and improving the overall environmental sustainability of the region. Although these plans are still required, the eligibility criteria for the funds were reduced and broadened such 
Table 1 - Toronto and Chicago in Numbers

\begin{tabular}{|c|c|c|c|c|}
\hline \multicolumn{5}{|c|}{$\begin{array}{l}\text { Toronto \& Chicago } \\
\text { In Numbers }\end{array}$} \\
\hline & \multicolumn{2}{|c|}{ Toronto } & \multicolumn{2}{|c|}{ Chicago } \\
\hline & Toronto - City & Toronto - GTHA & Chicago - City & Chicago - Metro \\
\hline Land Area' ${ }^{1}$ & $630 \mathrm{~km}^{2}$ & $8262 \mathrm{~km}^{2}$ & $606 \mathrm{~km}^{2}$ & 10544 km² \\
\hline Population ${ }^{2}$ & 2615060 & 6574140 & 2714856 & 8638474 \\
\hline Population density ${ }^{3}$ & $4149 / \mathrm{km}^{2}$ & $796 / \mathrm{km}^{2}$ & $4480 / \mathrm{km}^{2}$ & $819 / \mathrm{km}^{2}$ \\
\hline Pop. City/Pop. Metro & \multicolumn{2}{|c|}{$40 \%$} & \multicolumn{2}{|c|}{$31 \%$} \\
\hline Number of municipalities ${ }^{4}$ & \multicolumn{2}{|c|}{26} & \multicolumn{2}{|c|}{284} \\
\hline Number of regional municipalities (Ont.) or counties (III.) $)^{5}$ & \multicolumn{2}{|c|}{4} & \multicolumn{2}{|c|}{7} \\
\hline \multicolumn{5}{|c|}{$\begin{array}{l}\text { Note: Data for metropolitan regions pertain to the territory covered by the regional planning agencies of both regions, i.e., Metrolinx for the Greater Toronto and Hamilton Area and } \\
\text { CMAP for metropolitan Chicago. }\end{array}$} \\
\hline \multicolumn{5}{|l|}{ Source: Elaborated by the authors. } \\
\hline \multicolumn{5}{|c|}{${ }^{1}$ Toronto: Statistics Canada. 2012. Toronto, Ontario (Code 3520) and Ontario (Code 35) (table). Census Profile. 2011 Census. Statistics Canada Catalogue no. 98-316-XWE. } \\
\hline \multicolumn{5}{|c|}{ Ottawa. Released October 24, 2012. http://www12.statcan.gc.ca/census-recensement/2011/dp-pd/prof/index.cfm?Lang=E (Retrieved October 5, 2013). Chicago - Metro: } \\
\hline \multicolumn{5}{|c|}{ CMAP. 2005. Land Use Inventory. [0n line] htttp://www.cmap.illinois.gov/land-use-inventory. (Retrieved October 5, 2013). } \\
\hline \multicolumn{5}{|c|}{${ }^{2}$ Toronto in 2011: Statistics Canada. 2012. Toronto, Ontario (Code 3520) and Ontario (Code 35) (table). Census Profile. 2011 Census. Statistics Canada Catalogue no. 98-316- } \\
\hline \multicolumn{5}{|c|}{ XWE. Ottawa. Released October 24, 2012. http://www12.statcan.gc.ca/census-recensement/2011/dp-pd/prof/index.cfm?Lang=E (Retrieved October 5, 2013). Chicago } \\
\hline \multicolumn{5}{|c|}{ - City in 2010: "U.S. Census Bureau Delivers Illinois' 2010 Census Population Totals, Including First Look at Race and Hispanic Origin Data for Legislative Redistricting". U.S. Census } \\
\hline \multicolumn{5}{|c|}{ Bureau. (Retrieved October 5, 2013). Chicago - Metro in 2010: CMAP. http://www.cmap.illinois.gov/population-forecast. (Retrieved October 5, 2013) } \\
\hline \multicolumn{5}{|c|}{${ }^{3}$ Toronto: Statistics Canada. 2012. Toronto, Ontario (Code 3520) and Ontario (Code 35) (table). Census Profile. 2011 Census. Statistics Canada Catalogue no. 9} \\
\hline \multicolumn{5}{|c|}{ Ottawa. Released October 24, 2012. http://www12.statcan.gc.ca/census-recensement/2011/dp-pd/prof/index.cfm?Lang=E (Retrieved October 5, 2013). } \\
\hline \multirow{3}{*}{\multicolumn{5}{|c|}{$\begin{array}{l}{ }^{4} \text { Toronto: Régie des transports de la région du Grand Toronto. 2008. The Big Move. [On line]. http://www.metrolinx.com/thebigmove/Docs/big_move/081059_Metrolinx_ } \\
\text { TheBigMoveFR_V3_SM.pdf. (Retrieved October 5, 2013). Chicago: CMAP. 2005. About. [Online] http://www.cmap.illinois.gov/about. (Retrieved October 5, 2013). } \\
{ }^{5} \text { Toronto: Régie des transports de la region du Grand Toronto. 2008. The Big Move. [On line]. http://www.metrolinx.com/thebigmove/Docs/big_move/081059_MetroLinx_ }\end{array}$}} \\
\hline & & & & \\
\hline & & & & \\
\hline \multicolumn{5}{|c|}{ TheBigMoveFR_V3_SM.pdf. (Retrieved October 5, 2013). Chicago: CMAP. 2005. About. [Online] http://www.cmap.illinois.gov/about. (Retrieved October 5, 2013). } \\
\hline
\end{tabular}

that the emphasis on sustainability is no longer as strong as it was under the previous administration. However, the conservative government has made this transfer permanent, and it will be indexed to inflation (Respondent 59).

Provincial Government (Ontario) The provincial government of Ontario is a financial partner in transit expansion and improvement, planned by its own crown corporation, Metrolinx, and primarily operated by the Toronto Transit Commission (TTC). (Crown corporations are quasi-governmental enterprises established in Canada as service providers.) Moreover, in 2005, the liberal government of Prime Minister Dalton McGuinty adopted two major pieces of legislation related to land use: the Greenbelt Act and the Places to Grow Act. The Greenbelt Act and its associated Greenbelt Plan provide permanent protection to approximately 1.8 million acres of agricultural and ecologically sensitive land surrounding Toronto's metropolitan area, where urbanization should not occur. Complementing the Greenbelt Act, the Place to Grow Act allows the provincial government to identify regional growth centers that will allow for greater population and employment densities, managing the regional growth of an estimated 100,000 to 200,000 new residents per year. The maps in Figures 4 and 5 illustrate the protected land of the greenbelt and the growth areas subject to the growth plan.

Municipalities included in the growth plan areas have to conform to the law by updating their "official plan", i.e., the municipalities' comprehensive planning documents subject to a statutory 5-year review. Local decisions related to land use also must be enacted in conformity with the Greenbelt Act. As a complement to this growth management strategy, 


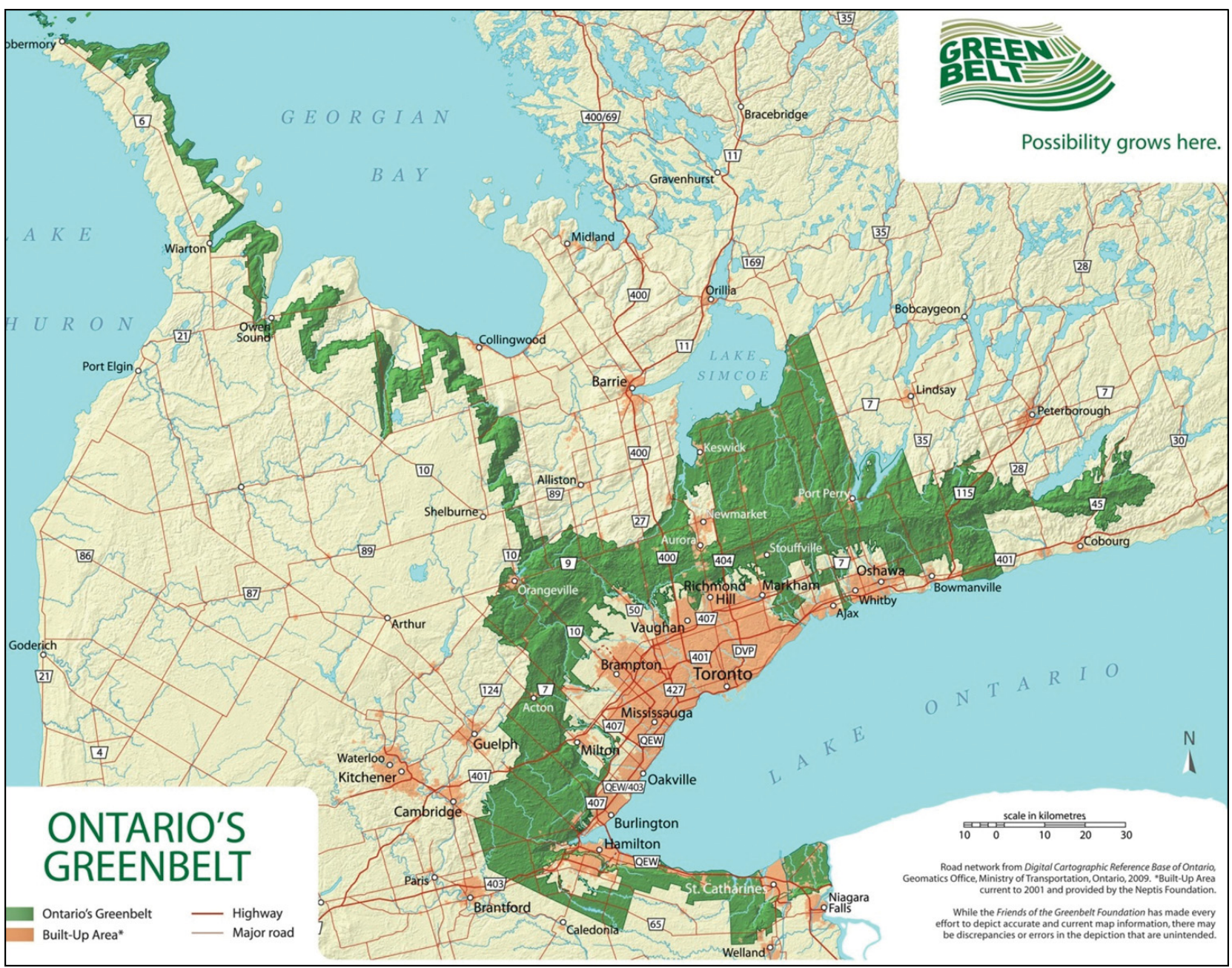

Figure 4 - Ontario's Greenbelt Map

Source: THE FRIENDS OF THE GREENBELT FOUNDATION, 2013.

in 2006, Ontario established Metrolinx, Toronto's metropolitan agency for transportation.

Metropolitan Agency (Metrolinx) Metrolinx is a crown agency under the purview of Ontario's Ministry of Transportation. Its mandate consists of the following: 1) operating GO Transit, the commuter bus and rail system; 2 ) implementing the regional light rail system and airport rail service, the Union Pearson Express; and 3) coordinating planning and fare integration for all transit services in the GTHA with the introduction of the PRESTO fare card. When it was created in 2006, its board of directors comprised local elected officials. The board's composition was changed after the adoption of the regional transportation plan, the Big Move, by replacing elected officials with non-elected members appointed by the minister and representing various sectors: banking, finance, legal, transportation and land use planning, and grassroots organizations, while ensuring geographic representativeness. The purpose of this transition from an elected to a non-elected board was to separate the plan's adoption from its implementation to ensure that elected officials adhered to the plan and facilitate its implementation (Respondent 59). Metrolinx contributes to the integration of transportation and land use planning in three distinct ways. First, the Big Move is intended to link regional growth centers by improving the quality and quantity of rapid transit options. Metrolinx also uses the Growth Plan's demographic data for its transportation demand model. Finally, the agency has created mobility hub pilot projects, such as the Kipling metro station, where the commuter rail line, subway, and roadway are better integrated with land uses. Two explicit objectives of Metrolinx are to have 


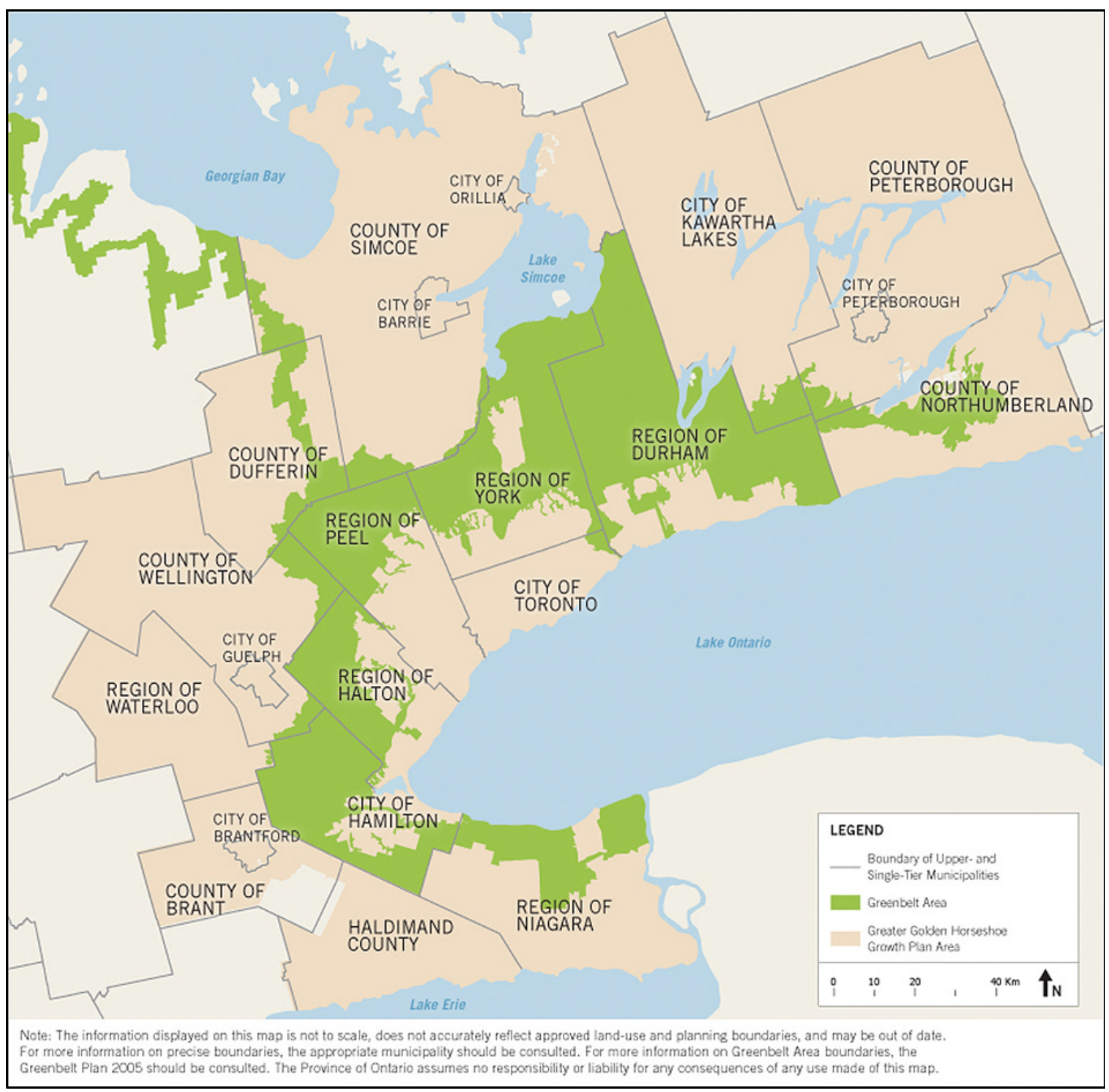

Figure 5 - Growth Areas for the Greater Golden Horseshoe

Source: ONTARI0, 2006.

$80 \%$ of the population living within two kilometers of a rapid transit station by 2031 and reduce the average regional commute time from 80 minutes to 70 minutes (Respondent 30).

Municipal Government (City of Toronto) Toronto's official plan directs demographic and employment growth towards areas where transit is already provided, in conformity with the Growth Plan. After a public hearing, the city designated the downtown core and four other urban centers (Scarborough, North York, Etobicoke and Yonge-Eglinton) as important growth zones, identified in red and beige in Figure 6.

Therefore, approximately $75 \%$ of the municipality's territory is comprised of residential neighborhoods, which will remain intact, and parks, where development is forbidden. Growth centers, marked in red, will be redeveloped and intensified. These areas represent $160 \mathrm{~km}$ of avenues lined with old commercial plazas, old retail plazas, small parking lots, and low-scale developments that are currently approximately 


\section{Map 2: Downtown and the Centres, City of Toronto}

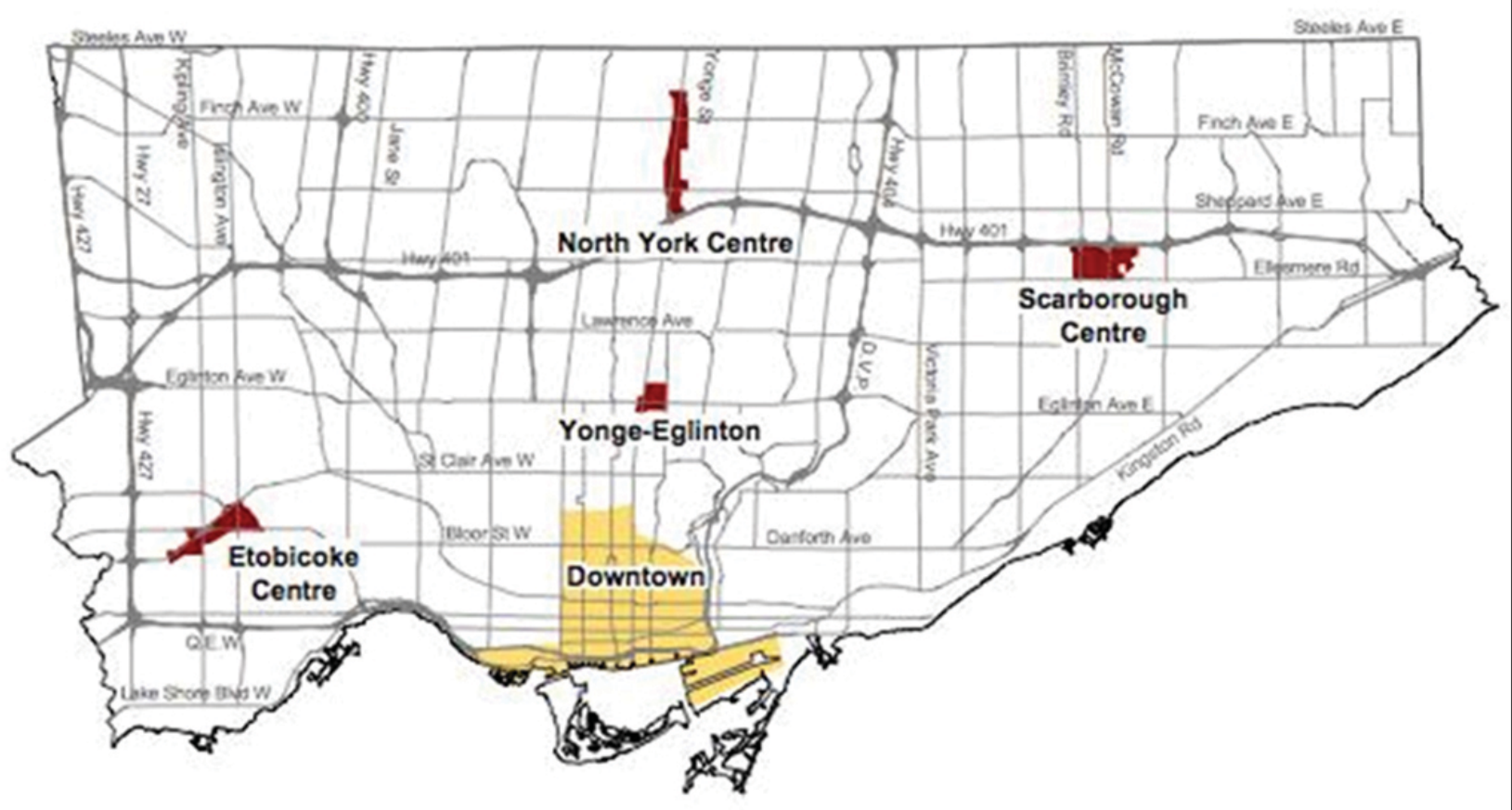

\section{Dall Toronto}

Figure 6 - Downtown and Growth Centers, City of Toronto

Source: URBAN TORONTO, 2012.

fifty years old. These zones are already served by transit and ready to be converted, intensified or replaced by six- or eight-story buildings that devote the ground floor to retail, allowing for a better use of the territory. The City of Toronto does not have a quantified objective in terms of modal share; its aim is to implement policies that increase the use of modes other than the private automobile, i.e., sustainable modes such as cycling and walking, which support the development of a "livable" urban region of neighborhoods with nearby services. (Respondent 25)

\section{Chicago}

Federal Government (Department of Transportation - DOT, Department of Housing and Urban Development - HUD \& Environmental Protection Agency - EPA) The American federal government is a major financial partner of transportation projects, channeling its investments through Metropolitan Planning Organizations (MPOs). In the U.S., the federal DOT has required the establishment of MPOs in all regions with over 50,000 residents since the adoption of the Interstate Highway Act of 1973. MPOs must develop a transportation improvement program subject to a variety of criteria determined by the DOT to qualify for federal transportation grant programs. A recent federal initiative, the Sustainable Communities Regional Planning Grant Program, piloted by the DOT in collaboration with HUD and the EPA, has helped MPOs to implement long-range plans by financing local projects that are collaborative in nature and include many aspects of planning (U.S. Department of Housing and Urban Development, 2011). In Chicago, this initiative translated into a $\$ 4.25$ million grant for CMAP's local technical assistance program, which has provided communities with the services of ten planners to update their zoning ordinances and implement projects respecting the principles of 
Go to 2040, the region's long-range transportation and land use plan.

State Government (Illinois) Respondents perceive the government of Illinois as a financial partner in transportation projects. The state collects sales tax dollars that are distributed by the Regional Transit Authority (RTA) to the three transit operators: 1) the Chicago Transit Authority (CTA), which provides bus and subway services for Chicago and 40 immediate suburbs; 2) Metra, the commuter rail operator; and 3) Pace, which provides bus services and adapted transportation in 200 Chicago suburbs. The respondents could not identify any specific policy or program dedicated to sustainable transportation and land use. However, in 2005, the state government merged the operations of the former transportation planning commission (Chicago Area Transportation Study - CATS) and the land use planning commission (Northeastern Illinois Planning Commission - NIPC) to create a single organization responsible for comprehensive regional planning, the Chicago Metropolitan Agency for Planning (CMAP), which also acts as the region's MPO. This institutional reform was the result of a two-year lobbying campaign instigated by a regional non-profit organization representing the business community, Chicago Metropolis 2020, which orchestrated a media campaign, developed a bipartisan coalition in Illinois' legislature, found legislative sponsors, and drafted the legislation that was unanimously adopted by the Illinois General Assembly. As described by one respondent:

[Members of Metropolis 2020] were the principal architects of the CMAP legislation...drafted the legislation, found sponsors, met with the governor, met with legislative leaders, fought with local government agencies who opposed it, fought with CATS and NIPC, because [they] opposed it obviously, but it happened. [The region is] much better off for it, because CMAP is now thinking, talking... [participants in CMAP] don't have all the tools, but at least [participants in CMAP] conceptually understand the connection between land use and transportation. (Respondent 43)

The establishment of Metropolis 2020, which changed its name to Metropolis Strategies in 2011, was motivated by the understanding that having two different agencies engaging in planning (one for land use and one for transportation) was no longer a coherent strategy. The initiative was also in sync with the long-standing involvement of the business community in the city's civic affairs that dates back to Daniel Burnham's Plan for Chicago, sponsored by the Commercial Club. Business-led civic organizations in Chicago are interested in regional transportation because it is perceived as a key component and a substantial driver of the city's economy (Respondent 37).

Metropolitan Agency (Chicago Metropolitan Agency for Planning - CMAP) CMAP is a quasigovernmental state agency led by a 15 -member board of directors: 5 members from the City of Chicago, appointed by the Mayor of Chicago; 5 from suburban Cook County, appointed by county mayors in conjunction with the President of the County Board; and 5 members representing the collar counties cooperatively appointed by the counties' mayors and chief elected county officials. Approximately half of the members are mayors, several are former elected officials, and the rest are from the business and civic community. Resolutions require 12 out of 15 votes to pass. The board's composition and voting rules were motivated by the desire to foster collaboration and consensus that motivated the creation of the organization (Respondent 37). CMAP's long-range comprehensive regional plan, Go to 2040, was unanimously adopted by its members in 2009, following an exhaustive consultation process that attracted attention from other MPOs for its use of MetroQuest, an online scenario visualization tool. Although CMAP does not have authority over land use and zoning, which remain under municipal jurisdiction, the implementation of Go to 2040 at the local level is facilitated by the technical assistance program funded through HUD's Sustainable Communities Regional Planning Grant Program.

Municipal Government (City of Chicago) The City of Chicago and the CTA collaborated in the development of a Transit Friendly Development Guide for the use of aldermen and private developers to encourage construction around transit stations and identify partnership opportunities for the redevelopment of properties owned by the city or CTA. This guide categorizes all 144 CTA stations in and outside the city and establishes a typology of 
seven types of stations characterized by different combinations of land use, density, activity, mix of uses and zoning surrounding the stations. However, the Transit Friendly Development Guide is only intended for informative and incentive purposes; it has no regulatory status. (Respondent 46)

\section{Discussion: Different paths of transition}

In Toronto, the integration of transportation and land use at the metropolitan level is pursued through official municipal plans that direct demographic and employment growth toward areas where transit is already provided, in conformity with provincial legislation, and through Metrolinx's mandate of providing better rapid transit options between growth areas. In Chicago, the integration primarily occurs through the implementation of CMAP's Go to 2040, with the help of the local technical assistance program, funded by the federal government. The leadership role played by Metropolis 2020 in instigating the merger of CATS and NIPC and the creation of CMAP, the mandate of which is to integrate transportation and land use planning, should not be overlooked.

The two regional planning agencies, Metrolinx (Toronto) and CMAP (Chicago), have different mandates and limited implementation capacities, which affect the types of activities they engage in and the way they operate. Whereas Metrolinx, a crown corporation of the government of Ontario, has the mandate of coordinating, funding, and operating transit services, CMAP, controlled by regional actors, has the responsibility to coordinate transportation with land use planning but limited funding and implementation capabilities. Moreover, because Metrolinx is both the transit owner and operator, it is likely that the provincial government will invest greater amounts over a longer period of time. That Metrolinx is under the purview of the Minister of Transportation allows for improved accountability for provincial investments. A respondent describes how this governance reform has changed the accountability framework:

In the past, a provincial government or federal government would give money directly as a grant to a municipality or to a transit agency.
And say, you know, here it is, you know, big announcement. And the accountabilities on that money would not necessarily [be] what I would call high in placing the customer first, right? So and the reason now Metrolinx has carriage of the funding is really in, the government is able to commit larger amounts because it can amortize over longer periods of time when its agency owns the asset. So the game changer, well here in the government, is that all the projects are being built with traditionally and the traditional, past way is the projects were owned and operated by the TTC or GO Transit, and now [Metrolinx] has the responsibility for the operation and maintenance of those assets to allow [Metrolinx] to amortize them to become [Metrolinx's] own assets. And I think that one of the groups like the TTC, who have, you know, basically been the experts in this field for a long, long time are being challenged by that. (Respondent 36)

By comparison, although CMAP has the responsibility to plan for the integration of transportation and land use planning, it does not have sufficient financial capacity or authority over zoning and land use to ensure the implementation of its long-range plan. Metropolis Strategies has recently campaigned for the consolidation of CMAP and the RTA, which would give CMAP the authority and resources to improve coordination of regional transit services, but its efforts have thus far fallen short.

Although the two reforms followed from different impulses, their ultimate goal was efficiency and coherence. Ontario's Greenbelt and growth management strategy were enacted by the liberal government of Prime Minister Dalton McGuinty, but they were originally initiated by the former conservative government of Prime Minister Mike Harris for the purpose of economic competitiveness and efficiency in government service delivery. The reform was motivated by the need to manage the fastest growing urban region in Canada. In Chicago, Metropolis 2020 was the primary instigator of the merger between CATS and NIPC and the creation of CMAP by the state government, and the organization's goal was to ensure coherence in the regional planning process, economic development, and environmental sustainability. This active 
involvement of the business community in civic affairs was in line with the historical development of the city. However, the fact that metropolitan Toronto is growing considerably more rapidly than metropolitan Chicago might explain the urge of the provincial government of Ontario to intervene more directly and coercively in regional transportation and land use development.

\section{Conclusions}

This study provides empirical evidence of the importance of vertical governance and regulation in the implementation of a metropolitan vision, as the intervention of Ontario's provincial government in the GTHA demonstrates. It also highlights the role (albeit limited) of horizontal governance and collaboration in facilitating consensus building and development surrounding transit stations at the neighborhood level, as in the case of Chicago and the CTA's transit station typology. The legislative lobbying campaign in Illinois that convinced the legislature to create CMAP illustrates how regional actors and civic capital can induce change at the state level. The case of Chicago, with more than 280 municipalities, two MPOs and one regional transportation authority, also exemplifies that extreme fragmentation at the regional level remains a major impediment to regional coordination. Even if the state of Illinois decided to implement some type of growth management strategy, it would still need to be implemented in a number of local jurisdictions, and ensuring conformity and accountability would be more challenging than in a metropolitan area with a smaller number of municipalities.

In essence, the political dynamics in Toronto and Chicago demonstrate how the capacity of local or metropolitan institutions to adopt and implement plans integrating transportation and land use aspects depends on leadership (the exercise of authority and law enforcement, power of initiative and consensus, and project implementation) from the province or the state government. Although the federal government can bypass the subnational level and intervene in local affairs by funding transportation projects that include land use planning, its capacity to promote a coherent metropolitan vision is inherently limited. The presence of a policy entrepreneur or a strong civic capacity at the regional level can also play a major role in the adoption and implementation of innovative reforms.

However, this study does not directly address the question of local conformity to the growth plan in Toronto and the implementation of regional plans at the local level, i.e., Go to 2040 in Chicago and the Big Move in Toronto. Additionally, it does not address the changes entailed by the creation of Metrolinx and CMAP on project selection and implementation or the different relationship that the two metropolises have with their provincial/ state governments and the resulting consequences for regional development. Future work is needed to assess plan implementation in both regions and the effects of Metrolinx's transition to a non-elected board on project selection and delivery. Other research avenues include the changes in power dynamics since the creation of the two regional institutions, their relationship with the public, and the development of indicators for measuring transportation and land use integration at the metropolitan and local levels.

\section{Acknowledgements}

This research was supported by the Fonds de recherche du Québec - Société et culture and Canada's Social Sciences and Humanities Research Council. The authors also wish to thank Carolyn Adams for copyediting and two anonymous reviewers for their useful comments on an earlier draft of this article.

\section{References}

ALEXANDER, L. The promise and perils of 'New Regionalist' approaches to sustainable communities. Fordham Urban Law Journal, v. 38, n. 3, p. 629-674, 2011.

BLACK, W. R. Sustainable transportation: problems and solutions. New York: Guilford Press, 2010.

BRENNER, N. Decoding the Newest 'Metropolitan Regionalism' in the USA: a critical overview. Cities, v. 19, n. 1, p. 3-21, 2002. http://dx.doi.org/10.1016/ S0264-2751(01)00042-7 
BROWN, D. Comparative climate change policy and federalism: an overview. Review of Policy Research, v. 29, n. 3, p. 322-333, 2012. http://dx.doi. org/10.1111/j.1541-1338.2012.00562.x

CALTHORPE, P.; FULTON, W. The regional city: planning for the end of Sprawl. Washington: Island Press, 2001.

CERVERO, R.; DUNCAN, M. Which reduces vehicle travel more: job-housing balance or retail-jousing mixing. Journal of the American Planning Association, v. 72, n. 4, p. 475-490, 2006. http://dx.doi. org/10.1080/01944360608976767

DEAL, B.; KIM, J. H.; CHAKRABORTY, A. Growth management and sustainable transport: do growth management policies promote transit use? Journal of Public Transportation, v. 12 , n. 4 , p. 21-40, 2009.

DOWNS, A. New visions for metropolitan America. Washington: Brookings Institution; Cambridge: Lincoln Institute of Land Policy, 1994.

FORSYTH, A.; OAKES, J. M.; SCHMITZ, K. H. Does residential density increase walking and other physical activity? Urban Studies, v. 44, n. 4, p. 679-697, 2007. http:// dx.doi.org/10.1080/00420980601184729

GIULIANO, G. The Weakening Transportation-Land use connection. Access, n. 6, p. 3-11, 1995.

HAMILTON, D.; HOKKANEN, L.; WOOD, C. Are we still stuck in traffic? Transportation in metropolitan areas. In: HAMILTON, D.; ATKINS, P. (Ed.). Urban and regional policies for metropolitan livability. London: M.E. Sharpe Publishers, 2008. p. 266-295. PMid:18314276.

HANDY, S.; CAO, X.; MOKHTARIAN, P. Correlation or causality between the built environment and travel behavior? Evidence from Northern California. Transportation Research Part D: Transport and Environment, v. 10, n. 6, p. 427-444, 2005. http://dx.doi. org/10.1016/j.trd.2005.05.002

HORAK, M.; YOUNG, R. (Ed.). Sites of governance: multilevel governance and policy making in Canada's big cities. Kingston: McGill-Queen's University Press, 2012.

JOHNSTON, R. The urban transportation planning process. In: HANSON, S.; GIULIANO, G. (Ed.). The geography of urban transportation. New York: Guilford Press, 2004. p. $115-140$.

KRAWCHENKO, T. Regional special purpose bodies for transportation and transit in Canada: case studies of translink and metrolinx. Canadian Journal of Regional Science, v. 34, n. 1, p. 1-18, 2011.

LEWIS, P.; SPRAGUE, M. Federal transportation policy $\&$ the role of metropolitan planning organizations in California. San Francisco: Public Policy Institute of California, 1997. Available at: <http://web.ppic.org/ content/pubs/report/R_497PLR.pdf>. Accessed in: 13 Feb. 2014.

LITTMANN, T. The New transportation planning paradigm. ITE Journal, v. 83, n. 6, p. 20-28, 2013.

MAAS, A. Area and power: a theory of local government. Glencoe: Free Press, 1959.

MARGERUM, R. et al. Regional transportation and land use decision making in metropolitan regions: finding from four case studies. Portland: Policy Consensus Initiative, 2011. Available at: <http://www. policyconsensus.org/publications/reports/trans_landuse. pdf>. Accessed in: 3 Mar. 2014.

NELLES, J. Cooperation and capacity? Exploring the sources and limits of city region governance partnerships. International Journal of Urban and Regional Research, v. 37, n. 4, p. 1349-1367, 2013. http://dx.doi. org/10.1111/j.1468-2427.2012.01112.x

NEUMAN, M. The compact city fallacy. Journal of Planning Education and Research, v. 25, n. 11, p. 11-26, 2005. http://dx.doi.org/10.1177/0739456X04270466

NORTON, A. International handbook of local and regional government: a comparative analysis of advanced democracies. Chenltenham: Edward Elgar, 1994. http:// dx.doi.org/10.4337/9781781954225

ONTARIO. Ministry of Infrastructure. Growth plan for the greater golden horseshoe. Toronto, 2006. Available at: $<$ https://www.placestogrow.ca/index.php?option=com_co ntent\&task=view\&id=9\&Itemid=14\&lang=eng $>$. Accessed in: 4 Oct. 2013.

ORFIELD, M. Metropolitics: a regional agenda for community and stability. Washington: Brookings Institution Press; Cambridge: The Lincoln Institute of Land Policy, 1997.

PIERRE, J.; PETERS, G. Urban governance. In: MOSSBERGER, K.; CLARKI, S.; JOHN, P. The Oxford Handbook of Urban Politics. Oxford: Oxford University Press, 2012. 
PORTER, D. R. State and regional initiatives for managing development: policy issues and practical concerns. Washington: Urban Land Institute, 1992.

RUSK, D. Cities without suburbs. Baltimore: John Hopkins University Press, 1993. PMid:8456829.

STATISTICS CANADA. Census profile. Ottawa, 2012. (Statistics Canada Catalogue, 98-316-XWE). Available at: <http://www12.statcan.gc.ca/census-recensement/2011/ dp-pd/prof/index.cfm?Lang=E $>$. Accessed in: 30 Sept. 2013.

SWANSTROM, T. What we argue about when we argue about regionalism. Journal of Urban Affairs, v. 23, n. 5, p. 479496, 2011. http://dx.doi.org/10.1111/0735-2166.00102 THE FRIENDS OF THE GREENBELT FOUNDATION. Ontario's Greenbelt map. Ontario, 2013. Available at: <http://greenbelt.ca/maps/greenbelt-map>. Accessed in: 4 Oct. 2013.

TIEBOUT, C. A pure theory of local expenditures. Journal of Political Economy, v. 64, n. 5, p. 416-424, 1956. http://dx.doi.org/10.1086/257839

TRANSPORTATION RESEARCH BOARD. Driving and the built environment: the effects of compact development on motorized travel, energy use, and CO2 emissions. Washington: National Academy Press, 2009. (Special Report, 298).

URBAN TORONTO. Downtown and the centers, city of Toronto. Toronto, 2012. Available at: <http:// urbantoronto.ca/news/2012/10/official-plan-torontosdevelopment-process>. Accessed in: 13 Oct. 2013.
U.S. ARMY CORPS OF ENGINEERS. Great Lakes Basin (Canada \& U.S.A). Detroit, 2007.

U.S. DEPARTMENT OF HOUSING AND URBAN DEVELOPMENT. HUD FY2011 sustainable communities grantees. Washington, 2011. Available at: <http:// portal.hud.gov/hudportal/HUD?src=/program_offices/ sustainable_housing_communities/sustainable_ communities_regional_planning_grants $>$. Accessed in: 31 Oct. 2013.

WEIR, M. Coalition building for regionalism. In: KATZ, B. (Ed.). Reflections on regionalism. Washington: Brookings Institutions Press, 2000. p. 127-153. PMid:10625287 PMCid:PMC1117382.

WEIR, M.; RONGERUDE, J.; ANSELL, C. Collaboration is not enough: virtuous cycles of reform in transportation policy. Urban Affairs Review, v. 44, n. 4, p. 455-489, 2009. http://dx.doi.org/10.1177/1078087408322590

WHEELER, S. The new regionalism: key characteristics of an emerging movement. Journal of the American Planning Association, v. 68, n. 3, p. 267-278, 2002. http://dx.doi.org/10.1080/01944360208976272

WOOD, R. 1400 governments. Cambridge: Harvard University Press, 1961.

Recebido: 01/01/2014 Received: 01/01/2014

Aprovado: 20/03/2014 Approved: 03/20/2014 